\title{
RENOVATION AND MODERNIZATION OF HOTEL BUILDINGS - CASE STUDIES IN SILESIA
}

\author{
Tomasz BRADECKI ${ }^{1}$, Barbara UHEREK-BRADECKA \\ Silesian University of Technology, Faculty of Architecture, Gliwice, Poland
}

\begin{abstract}
The cultural heritage of Silesia has different backgrounds and is often characterized by difficult to assess values. There is doubt as to whether some of the existing buildings should be modernized. Since 2000, an increase in the amount of investments in hotel buildings and conference venues in Poland has been observed. The functions and roles of hotels within a city have also changed. The paper presents examples of original projects and realizations of hotel buildings in Silesia. A discussion was also held regarding the issue of adapting and modernizing hotel buildings.
\end{abstract}

Keywords: Silesian heritage, hotel conservation, hotel modernization

\section{INTRODUCTION}

Cultural heritage in Silesia has many backgrounds, and is often characterized by difficult to assess values. There are exceptional examples of architecture and city planning typical of this region: industrial neighborhoods (patron settlements), the remains of industrial buildings, including mines, architecture possessing characteristic traits in terms of style, e.g. clinker brick as a finishing element, laid in a specific manner, or others. The vast majority of the buildings, however, either completely lack such features or only partially attest to the region.

Some of these buildings are found in the centers of cities and it would appear that their role is quite significant, considering as how they constitute proof of

\footnotetext{
1 Corresponding author: Silesian University of Technology, Faculty of Architecture, Akademicka st 7, 44-100 Gliwice, Poland, e-mail: tomasz.bradecki@polsl.pl, barbara.uherek@polsl.pl, tel.+487930909078
} 
the past, very visible and often unchanged to this very day. As written by Janowski Z., Janowski M. (6), the revitalization and renovation of historic buildings in the center of cities is a commitment.

\section{HOTEL BUILDINGS AND CURRENT TRENDS}

Since the year 2000, one can observe an increase in the number of investments made in hotel and hotel-conference buildings; the role and potential which these types of functions serve in urban space, in Silesia as well as in Poland, is also changing (based on data from GUS). In the years 2002-2013, the combined number of hotels in Poland doubled, of which many hotels increased their standard or were built to meet 4-star standard in the years 2009-2013. As far as investments in the hotel market in the Silesian voivodeship are concerned, it is ranked $4^{\text {th }}$ in the country. It is worth noting here that not all investments are new projects: some of them are reconstructions or modernizations aimed at improving quality. The process of improving the image of hotels by modifications of the product can be realized by changing the interior design (changes in furnishings/fittings) or adding on to and reconstructing entire buildings (4).

There are 156 hotels in the Silesian voivodeship (as of 2010) and the number is increasing (according to data from GUS). A small amount of them are found in buildings under preservation maintenance or created in already existing buildings, however the majority of new hotels are in newly constructed buildings. In the majority of cases these hotels target business clients who travel and stay in larger cities, where the location of hotels allows for quick travel to main transportation networks and hubs. In the recent years, a tendency for an increasing number of hotels to stand out in terms of esthetics has been observed: starting from the development of the surrounding land property, to unique architecture and interior design. Their functions have also become increasingly diverse: hotel functions are often complete with conference, spa, wellness, recreational and other facilities. This results in the greater spatial variation of the buildings and diversity in their architecture.

\section{CASE STUDY}

The article presents two cases of hotel building renovations, designed by the authors. Both are examples of 4-star hotels in which the renovation process was based on adapting the functional layout to the needs in of the given standard and on significant intervention in terms of interior design. 


\subsection{Case study of hotel in Zabrze}

Hotel Diament in Zabrze presented in the article can serve as an excellent example of how the modernization of single buildings can influence the revitalization of a large urban area. The building is located in the area of South Zabrze (Zabrze Południe), in the direct vicinity of the Guido mine, which currently functions as a museum of considerable supralocal importance. The building originally served as a hotel for workers, similarly to a few others like it located in the area. Gradually, more and more of the buildings were turned into residential dwellings, and in the 90's, one of them, along with the canteen, was transformed into a three-star hotel along with a restaurant. In 2013, an additional restaurant building, belonging to the already existing complex, was completed (marked in Fig. 1). The high standard clearly set it apart from the somewhat neglected buildings in the neighborhood and provided the area with a new quality. Functionally connected to the existing restaurant, the building serves as a conference, banquet and exposition hall. The untypical dimensions of the hall: nearly $12 \mathrm{~m}$ span x $38 \mathrm{~m}$ lacking support columns, as well as the expansive terrace, approx. $300 \mathrm{~m}^{2}$, provide the space necessary to organize many untypical social gatherings on a large scale. Much attention was paid to the interiors: an assortment of lighting and an untypical finish of the ceilings distinguish the hall from other similar facilities in Silesia. Taking advantage of the fact that the restaurant was being added on to, the entrance area was renovated along with the existing restaurant (which had originally served as the dining area of the canteen).
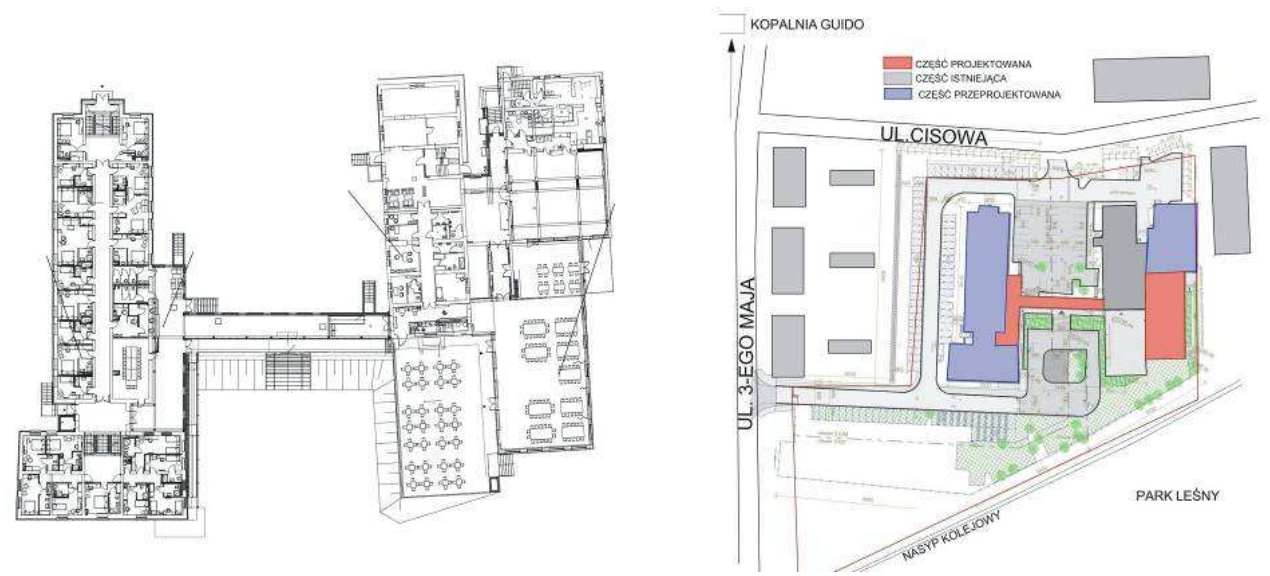

Fig. 1. Layout diagram of the location of buildings in the neighborhood of Guido mine, an operating narrow-gauge railway and remaining buildings of former workers' hotels; layout diagram of a hotel building complex along with the connector following reconstruction, prepared by: Tomasz Bradecki 
In 2014, the reconstruction of the last abandoned building of the workers' hotel into a four-star hotel connected with the 3-star hotel, along with the development of the surrounding land property was completed. The total surface area of the entire undertaking - approx. 5 thousand square meters, making for a total of 180 beds, and 600 square meters of restaurant and conference space, causes the entire complex to stand out not only in the city of Zabrze, but also on the scale of the entire region of Silesia. The existing hotel building which was reconstructed into four-star section was not a historical property and not under historic preservation maintenance, whereas its specific form (in the shape of the letter T) and functional layout (corridor-type building with two representative spacious stairwells) make for elements typical of post-war architecture. In the opinion of the authors, the lack of clear details in the elevation is not a flaw. The horizontal structure of the building makes it possible to remove partition walls and freely arrange the layout of the interior. The partially deepened basement made it possible to create a multi-functional conference-banquet hall with an untypical layout. Originally, the boiler house and technical room were located there. Hotel rooms were created in the large majority of spaces along the corridors, with the exception of the part serving as the reception area. Both of the buildings (3- and 4-star section) were connected with a newly designed glazed building serving as a corridor and lobby. A contemporary reinterpretation of rustication in the elevation was carried out on a part of the existing building, from the side of the lobby. It was created using aluminum profiles to give it a more contemporary character. All of the newly designed buildings have a consistent yet distinctive (from existing ones) character as a result of their architectural design: large windows, decorative overhangs covered with laminate board, and linear lighting of the exterior (Fig. 2).

The authors believe that if we agree with the notion that relics ought not to be built but creatively transformed (6), this has been accomplished in the carried out concept.

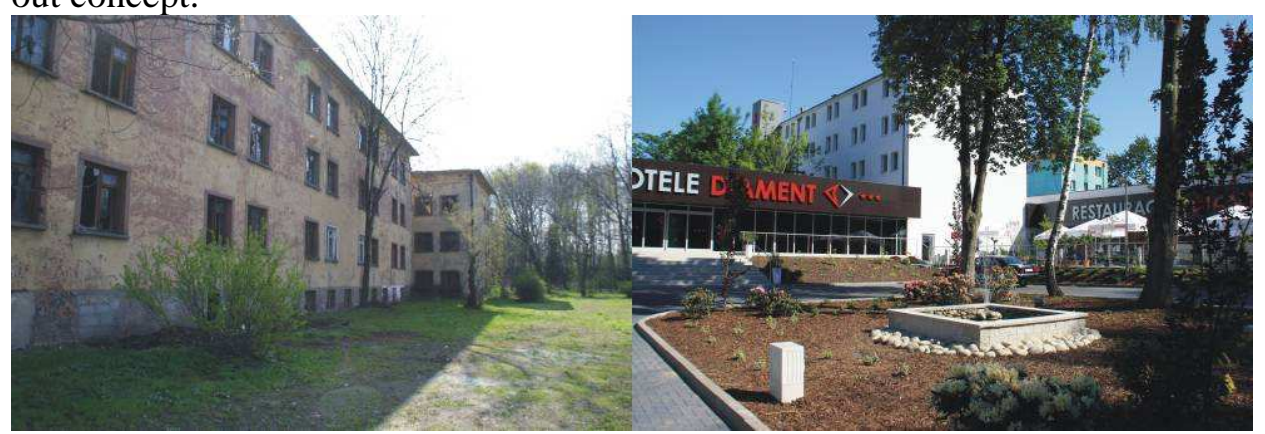

Fig. 2. Hotel Diament in Zabrze next to Cisowa street: view prior to and after modernization 
During the renovation of the hotel building in Zabrze, particular attention was given to interior design. Inside, some elements of design were to reflect local traditions: elements of clinker brick as wall cladding were used, as well as photographs of important buildings and public use facilities located in the direct neighborhood of the hotel (Fig. 3). As written by Jeonglyeol Lee (7), the design of the hotel ought to consider its location and use it as an attribute and advertisement, emphasizing the area in which it is located. This can have an influence on better economic results of the building serving such a function. Work on the hotel involved not only architects, but also specialists in marketing, advertising and PR. Thanks to this, attention was paid to make the interiors consistent in appearance and create an "atmosphere" of hospitality, which can be effective in shaping the success of a given place, as it is of significant importance to the guests (5).

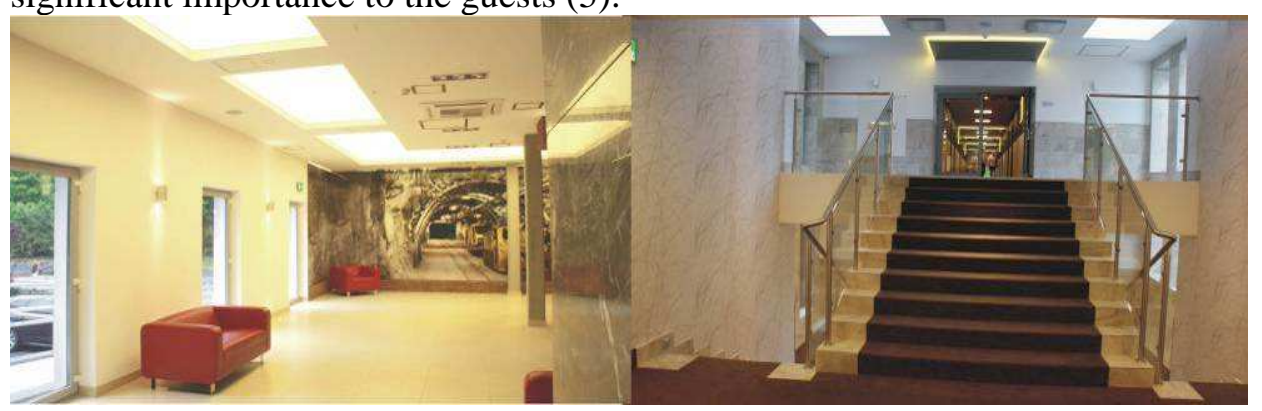

Fig. 3. The inside of Hotel Diament in Zabrze on the left - the hotel lobby with a fragment of an image of the nearby Guido mine, on the right - the exhibited representative stairwell

\subsection{Case of Hotel in Katowice}

The Hotel Diament building in Katowice is found in the direct neighborhood of Hotel Monopol (Fig. 4) - a historic building with a history of functioning as a hotel for the last few dozen years. Hotel Monopol underwent complete renovation with rather good effects (6) - to this day it is a symbol of the quality of function and space within the city center.

Thorough modernization of hotel Diament in Katowice (accord. to a project by Grudnik, Gomolla, Kałdonek) was carried out in 2001, with the hotel attaining 3 -star status. The building is characterized by an untypical functional layout: all corridors and rooms are placed around a central, very narrow courtyard. In 2012, the modernization of the hotel to a 4-star standard was completed, based a project by the authors. The elevation, which contains stucco works serving as proof of the historic background of the building, was not changed 
significantly from the prototype: the stucco work was retained, a soft light color palette was maintained.

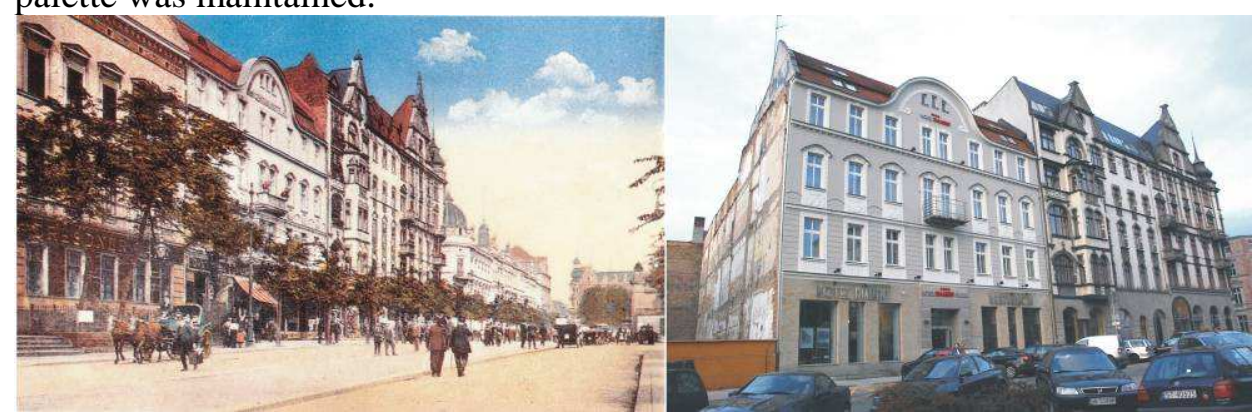

Fig. 4. Hotel Diament in Katowice next to Dworcowa Street - historic photo and state following renovation

The modernization of the hotel which took place during the years 2011-2012 (authors Uherek-Bradecka, Tomasz Bradecki) was aimed at providing the interior with new, original esthetics, increasing the standard and adapting the hotel to a 4-star standard. Due to the fact that this involved an already existing building and the possibilities of its adaptation were somewhat limited (development in the immediate city center, stairwell and elevation subjected to historical preservation maintenance (see Fig. 5)), it was possible to meet the categorization requirements despite the fact that not all requirements set out for newly-constructed buildings were fulfilled $(1,2)$. Original bricks (as had been done previously) were left in the corridors of the hotel as a finishing element, whereas the walls of some other parts of corridors were finished with a coating of raw concrete (Fig. 5). The hotel rooms anticipated a solution which brought about associations with the historical past: wallpapers finished with decorative profiles, the same as those used in the past to create ornamental moldings (Fig. 5).

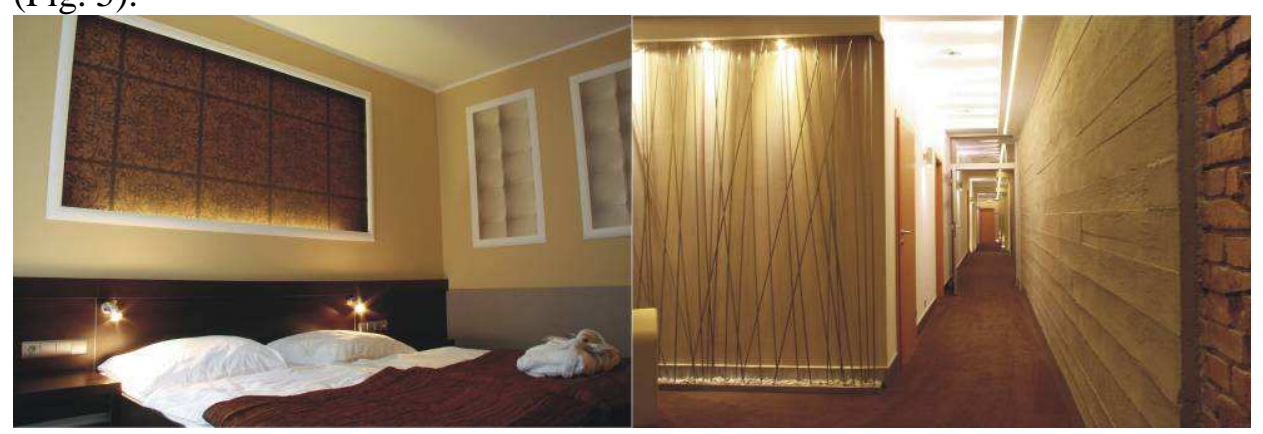

Fig. 5. Interior of hotel room following modernization (on the left), hotel corridor on the right (photograph by T. Bradecki) 
Similarly to other cases of renovating historical monuments, but not only, a historic building can make an impression, as well as serve its functional use and constitute an important element of the cultural heritage of a given city or region (3). The authors believe that this continues to be so in the case of Hotel Diament in Katowice to this day.

\section{CONCLUSIONS}

According to Hassanien (4), renovations can lead to success, especially in cases when the renovation concept is connected with a concept for managing and using the building. In both of the described cases, the final effect is the combined result of not only architects, but also the investors consulting the project and staff attending to the guests; the realization as well as the guidelines for the design were directly connected with experience from the past and anticipated future use of these types of buildings. It seems as though the scale and role of hotel buildings in cities is rather significant, and their importance continues to increase. The analyses carried out and conclusions drawn from the article serve as proof of the above thesis and can be useful when assuming possible similar investments in the future: renovation or modernization of buildings.

As Judy Signaw and Cathy A. Enz (9) put it, "the best hotels are using architecture and design to add value to the quests experience." One might add that the quality of architecture that hotels present is of key importance to their success.

\section{REFERENCES}

1. Błądek Zenon, Włodzimierz Błądek, Sławomir Manikowski: Nowoczesne hotelarstw' Wydawnictwo: Palladium, 2013, ISBN: 978-83-7821-041-2.

2. Błądek Zenon: Hotele - Programowanie, projektowanie, wyposażanie. Wydawnictwo: Palladium, 2001, ISBN: 83-916093-0-8.

3. Deja, Barbara Maria: Remont i adaptacja zabytkowej olsztyńskiej kamienicy na budynek hotelowy Wydawnictwo Politechniki Krakowskiej im. Tadeusza Kościuszki Czasopismo Techniczne. Budownictwo 2011,R. 108, z. 3-B, Strony 19-33.

4. Hassanien Ahmed: Exploring hotel renovation in large hotels: a multiple case study, Structural Survey, Vol. 24 Iss: 1, pp.41 - 64 (2006), ISSN: 0263080X, http://dx.doi.org/10.1108/02630800610654414.

5. Heidea Morten, Kirsti Lærdala, Kjell Grønhaugb: The design and management of ambience-Implications for hotel architecture and service 
Tourism Management Volume 28, Issue 5, October 2007, Pages 1315-1325, doi:10.1016/j.tourman. 2007.01.011.

6. Janowski Z, Janowski M.: Problemy projektowe zwiazane $z$ adaptacja budynków zabytkowych na cele użyteczności publicznej, Wydawnictwo Politechniki Krakowskiej im. Tadeusza Kościuszki Czasopismo Techniczne. Budownictwo, 2009, R. 106, z. 2-B, Strony 139-150.

7. Jeonglyeol Timothy Lee: Role of hotel design in enhancing destination branding. Annals of Tourism Research Volume' 38, Issue 2, April 2011, Pages 708-711.

8. RAPORT 2014 Rynek Hotelarski w Polsce Wydanie specjalne miesięcznika ŚWIAT HOTELI lipiec-sierpień http://data.axmag.com/ data/201408/20140820/U44451_F297535/media.pdf.

9. Signaw Judy A., Enz Cathy A. Enz.: Best Practicies in Hotel Architecture. Cornell hotel and restaurant administration quarterly',Volume 40, Issue 5, October 1999, Pages 44-49, 4, doi:10.1016/S0010-8804(99)80232-8.

\section{RENOWACJA I MODERNIZACJA BUDYNKÓW HOTELOWYCH NA PRZYKŁADZIE PROJEKTÓW I REALIZACJI NA ŚLĄSKU}

\section{Streszczenie}

Dziedzictwo kulturowe na Śląsku posiada różne rodowody i często charakteryzuje się trudnymi do oszacowania wartościami. Niektóre z istniejących obecnie budynków pozostają pod znakiem zapytania, czy warto je modernizować. Od 2000r. aż do dziś można zaobserwować wzrost ilości inwestycji w budynki hotelowe i hotelowokonferencyjne, zmienia się również rola i potencjał jaki pełnią tego typu funkcje w przestrzeni miejskiej. W artykule przedstawiono przykłady autorskich projektów i realizacji budynków hotelowo-konferencyjnych na Śląsku oraz przeprowadzono dyskusję na temat problematyki adaptacji i modernizacji budynków do funkcji hotelowych.

Słowa kluczowe: hotele, renowacja hoteli, dziedzictwo kulturowe 